Bulletin of the Natural History Museum, 2018, 11: 7-17.

Received 17 Oct 2018; Accepted 11 Dec 2018.

doi:10.5937/bnhmb1811007M

UDC: 569:551.78(497.6)

Original scientific paper

\title{
PALEONTOLOGICAL RESEARCH ON FOSSIL SMALL MAMMALS FROM THE OPEN-PIT COAL MINES OF BOSNIA AND HERZEGOVINA - OVERVIEW OF RESULTS
}

\author{
ZORAN MARKOVIĆ $^{1 *}$, MILOŠ MILIVOJEVIĆ ${ }^{1}$, HANS DE BRUIJN ${ }^{2}$, \\ WILMA WESSELS ${ }^{2}$, ANDREW A. VAN DE WEERD ${ }^{2}$, SVETLANA RENOVICA ${ }^{3}$, \\ ENES ŠIŠIĆ ${ }^{4}$ KASIM MODRIĆ ${ }^{4}$ \\ ${ }^{1}$ Natural History Museum in Belgrade, Njegoševa 51, 11000 Belgrade, Serbia, \\ e-mail: zoran.markovic@nhmbeo \\ ${ }^{2}$ Department of Earth Sciences, Utrecht University, Princetonlaan 8A, 3584 CB \\ Utrecht, the Netherlands \\ ${ }^{3}$ RiTE Ugljevik, Ugljevik 76330, Bosnia and Herzegovina \\ ${ }^{4}$ RMU Banovići, Armije BiH 52, 75290 Banovići, Bosnia and Herzegovina
}

Fossil remains of Tertiary small mammals were found on four open-pit coal mines in Bosnia and Herzegovina. Three of them are the Oligocene/Oligo-Miocene in age "Bogutovo Selo" and "Luke Mezgraja" - Ugljevik Basin and "Turija" Banovići Basin), while one belongs to the Middle Miocene, "Gračanica" - Bugojno Basin.

Keywords: Tertiary, small mammals, coal mines, Bosnia and Herzegovina.

\section{INTRODUCTION}

Until the beginning of the $21^{\text {st }}$ century, research on fossil Tertiary mammals found in the territory of Bosnia and Herzegovina consisted mainly of accidental finds of parts of large mammals - mainly common 
representatives of fauna that used to inhabit the region. Most of the remains are not collected and prepared in a scientific manner and are currently kept in the collections of institutions and individuals; only a small number of them have been described and published in scientific journals.

Systematic research began in 2004, initiated by fragments of mammals accidentally discovered in coal which in 1993 was used to heat the offices of the Natural History Museum in Belgrade. From the procurement documents, it appeared that the coal originated from the "Bogutovo Selo" open-pit mine, near Ugljevik (Bosnia and Herzegovina). The fossils were mainly fragments of the long bones of the extremities of some large mammals - most likely including Anthracotherium minus and Cadurchotherium rakoveci, whose remains had been discovered earlier (Laskarev 1925, Malez \& Slišković 1976, Malez \& Thenius 1985). Remains of small mammals, fish, amphibians, reptiles and birds were also observed in pieces of coal. Fortunately, the remains of small mammals included wellpreserved teeth, which made their identification possible. Representatives of a cricetide rodent, at that time unknown to science, were prevalent and were informally named by Marković as "Cricella trident". The fact that this was something completely new was confirmed also by foreign experts, among them Hans de Bruijn, eminent paleozoologist from the University of Utrecht. As a long standing member of many teams doing research throughout Euro-Asia, he showed the great interest in this discovery of Tertiary mammals from the Central Balkans.

\section{RESULTS}

Joint fieldwork and intensive scientific cooperation between the Natural History Museum in Belgrade and the University of Utrecht started in 2003, a year later in 2004 a team consisting of experts from both institutions organized the first detailed exploration of the "Bogutovo Selo" open-pit mine in Ugljevik.

First, we had to find the most promising fossil-bearing layers and next we had the find the best way to extract the fossils from the coal. We initially tried to wash the coal using a system of sieves, this method proved unsuccessful because the coal did not disintegrate. Next, we switched to isolate the fossils from the coal by hand. In addition, we disintegrated the fossiliferous coal pieces in water with some added peroxide. This proved successful, coal disintegrated into small ( $\mathrm{cm}$ and $\mathrm{mm}$ ) pieces. Next the residue consisting of coal fragments and a few fossils was enriched using "the gold-panning method". Finally, we used the microscope to pick the small fossils from the enriched residue. In this way, we managed to collect 
numerous remains of fossil small animals that complemented the picture from 1993.

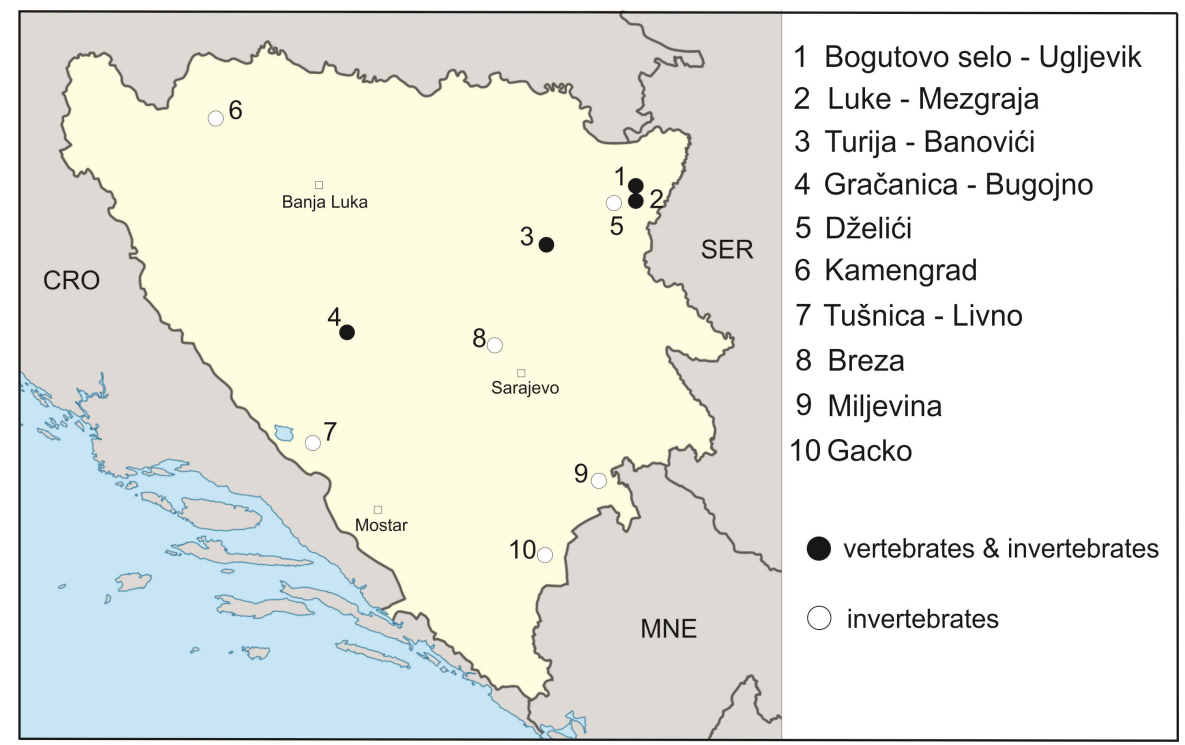

Fig. 1. - Map of Bosnia and Herzegovina, with locations of open-pit coal mines in which fossil remains have been found.

When the team joined the Project "Evolution within isolated ecosystems: The Neogene Dinaride lake system", headed by Oleg Mandic from the Natural History Museum in Vienna, our research was extended to open-pit coal mines in the entire territory of Bosnia and Herzegovina. Seven coal mines were explored during 2007 and 2008. Two new sites with fossil small mammals were discovered, one in the open pit mines of the "Turija" (RMU Banovići) of Late Oligocene age and one in "Gračanica" near Bugojno of Middle Miocene age. In these localities, the fossils were found in under- and overlying clay beds and collected by screen washing of the sediments. The fauna from "Turija" is very rich and diverse (de Bruijn et al. 2013). The discovery of the Middle Miocene small mammals in "Gračanica" (Stefen 2019, Wessels et al. 2019) confirmed the earlier estimate of the geological age which was based on fossil large mammals. The latest papers to discuss large mammals from the "Gračanica" mine are Aiglstorfer \& Mayda (2018), Bastl et al. (2018), Backer \& Tissier (2019) and Coombs \& Göhlich (2019). Remains of invertebrates and flora were found in other mines (Fig. 1).

Due to the coal exploitation the configuration of the large mine concession areas changed rapidly over time: new parts of the concession area are opened, while old parts disappeared and become inaccessible due to the storage and dumping of overburden and re-cultivation. Together with our colleagues from the geological services of the mines, new recon- 
naissance was carried out in June 2018 by the experts from the Natural History Museum (Zoran Marković and Miloš Milivojević) and the University of Utrecht (Wilma Wessels and Andrew van de Weerd). Planned activities started at the open-pit coal mine "Bogutovo Selo" (RiTE Ugljevik) and samples showed that remains of vertebrates were still present in the currently exploited coal seams (Fig.2).

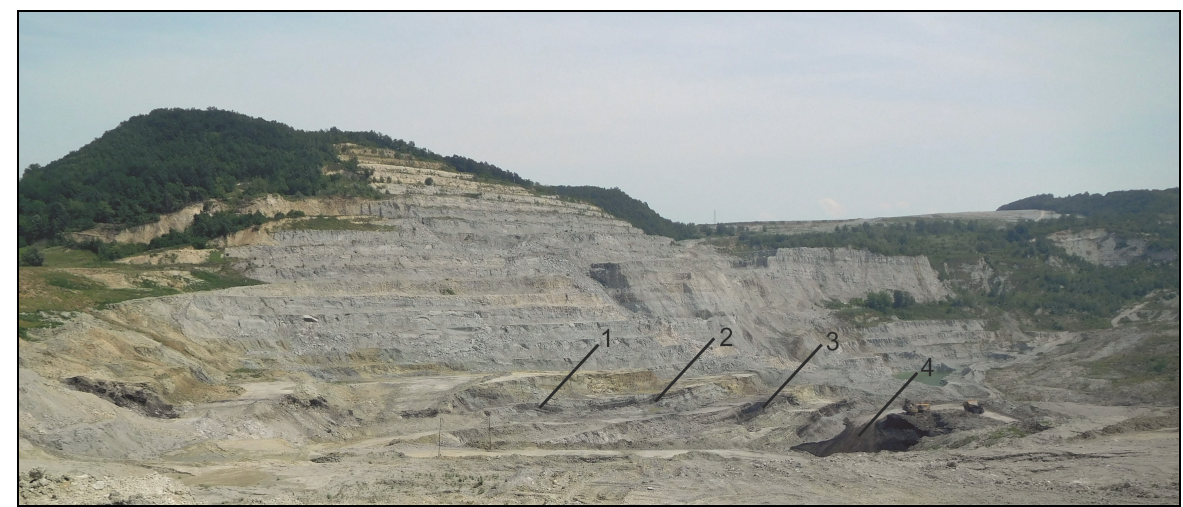

Fig. 2. - Open-pit coal mine of the "Bogutovo Selo", RiTE Ugljevik: 1, 2, 3 and 4- the location where fragments of fossil mammals were found.

In addition, we investigated the relatively small pit "Luke Mezgraja" that was opened in 2011. This mine is located about $10 \mathrm{~km}$ south of Uglje-

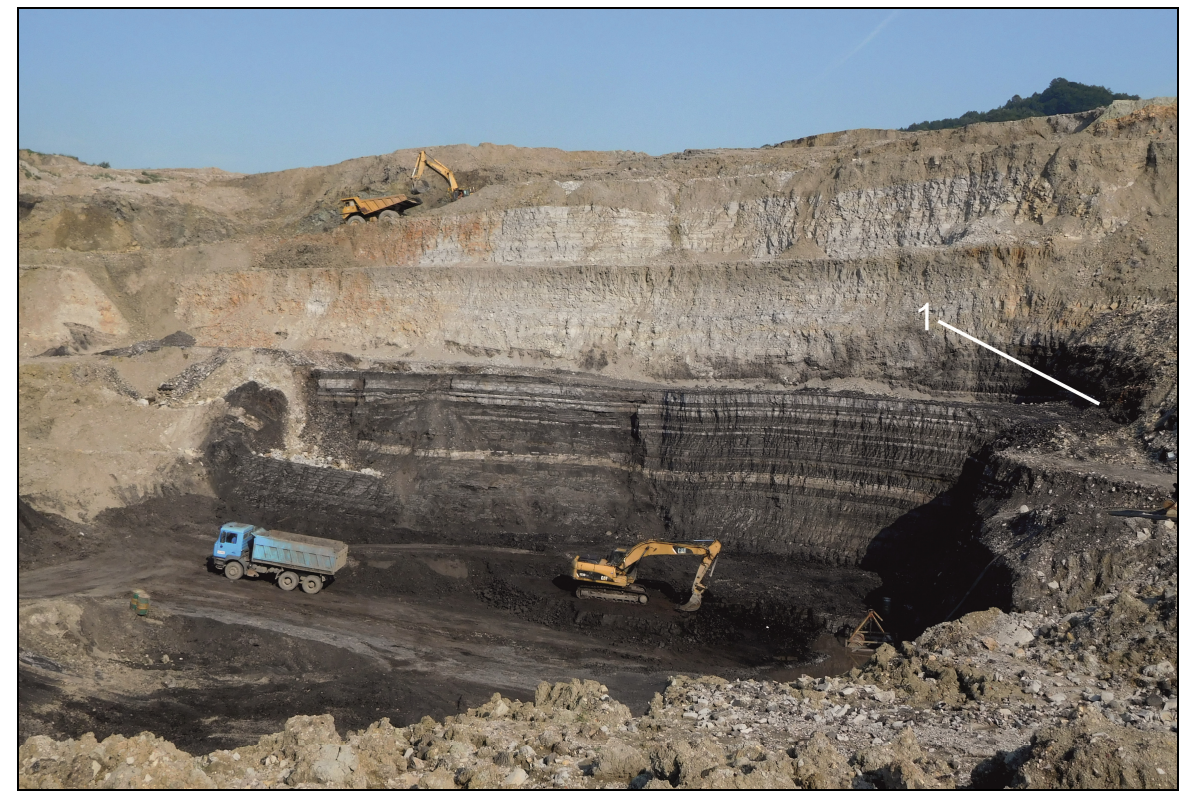

Fig. 3. - "Luke Mezgraja", open-pit coal mine with identical fossil fauna as that found in "Bogutovo Selo"; 1) Location where the remains of fossil vertebrates were discovered. 
vik (Fig. 3). Fossils of small mammals were discovered among the numerous remains of lower vertebrates, such as fish, lizards and frogs. Preliminary results suggest that this fauna is similar to that of "Bogutovo Selo", and that the fossil-bearing coal seam is the same (Fig. 4.).

Due to the character of the coals in "Bogutovo Selo" and "Luke Mezgraja" the separation of the fossils remains require a detailed inspection of each individual piece of coal. Appropriate tools need to be used in order not to damage the fragile fossils; consequently, preparation and conservation is best performed on site.

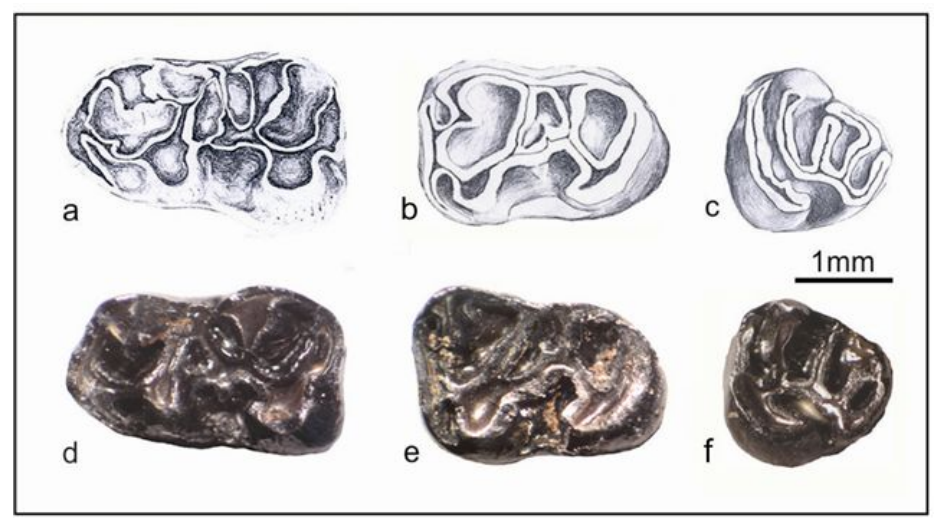

Fig. 4. - Illustration of the molars of a large cricetid rodent from the Ugljevik - "Bogutovo Selo" coal found in the Natural History Museum in Belgrade. a) $\mathrm{m} 1$, b) $\mathrm{m} 3$, c) M3; photographs of the molars of probably the same animal found in "Luke Mezgraja": d) m1, e) m3, f) M3.

The short field visit in 2018 to RMU Banovići included a tour of the open-pit coal mine "Turija". The purpose was to relocate the old site were in 2008 a rich fossil fauna was discovered (de Leeuw et al. 2011). It was established that the fossiliferous clay layers sampled in 2008 no longer existed and the location was inaccessible due to the intensive coal exploitation between 2008 and 2018 (Fig. 5). The appearance of the coal mine itself had completely changed during these years. Due to the bad weather and the muddy terrain we were somewhat restricted during our 2018 visit, but we were able to take a small sample in the south-western part of the pit in a layer of coal-rich sediment, stratigraphically younger than the main coal seam (see Fig. 6). Samples were taken from a yellowishgreenish clay bed. After drying the sample, it was washed using the vibrating sieve machine developed by the Museum in Belgrade. The residue was examined, but, unfortunately the sample contained no fossil vertebrates, but abundant fossils gastropods and algae (Chara) were present. Such fossils are not new to science but were found earlier during 
the stratigraphic studies of the Banovići Basin (Muftić \& Luburić 1963, Vrabac et al. 2005).

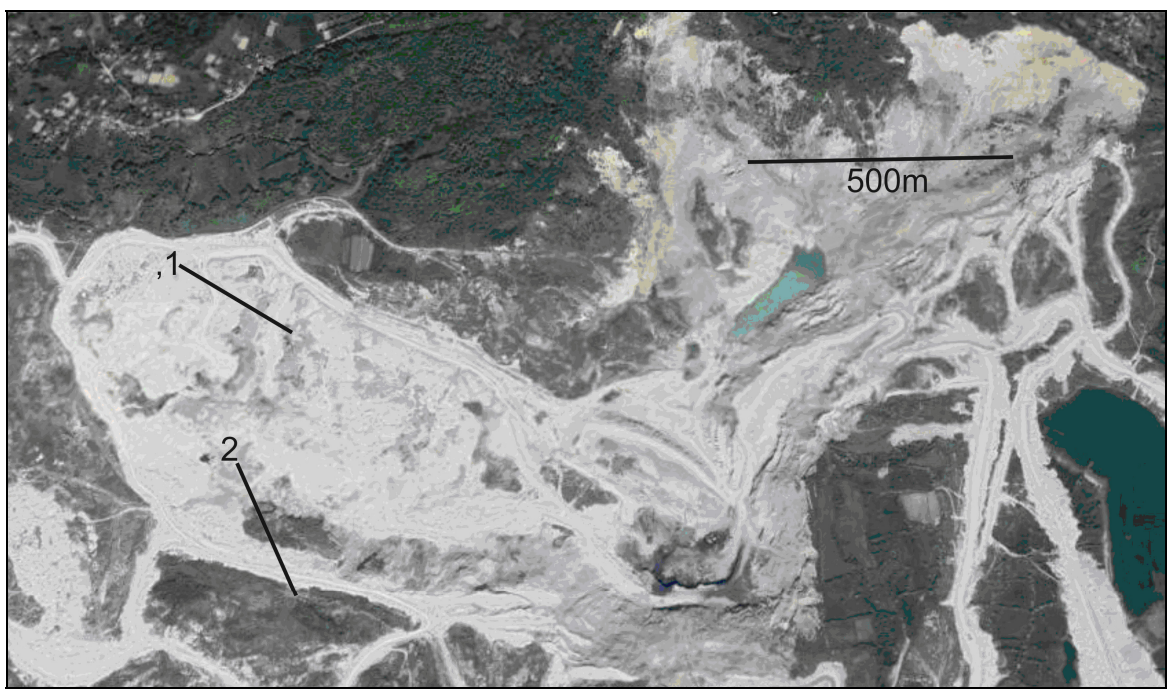

Fig. 5. - Satellite image of the open-pit "Turija”, RMU Banovići (April, 2018 Google Earth); 1) the site where excavations were carried out in 2007 and 2008 now covered by overburden waste, 2) location from which sample was taken in June 2018.

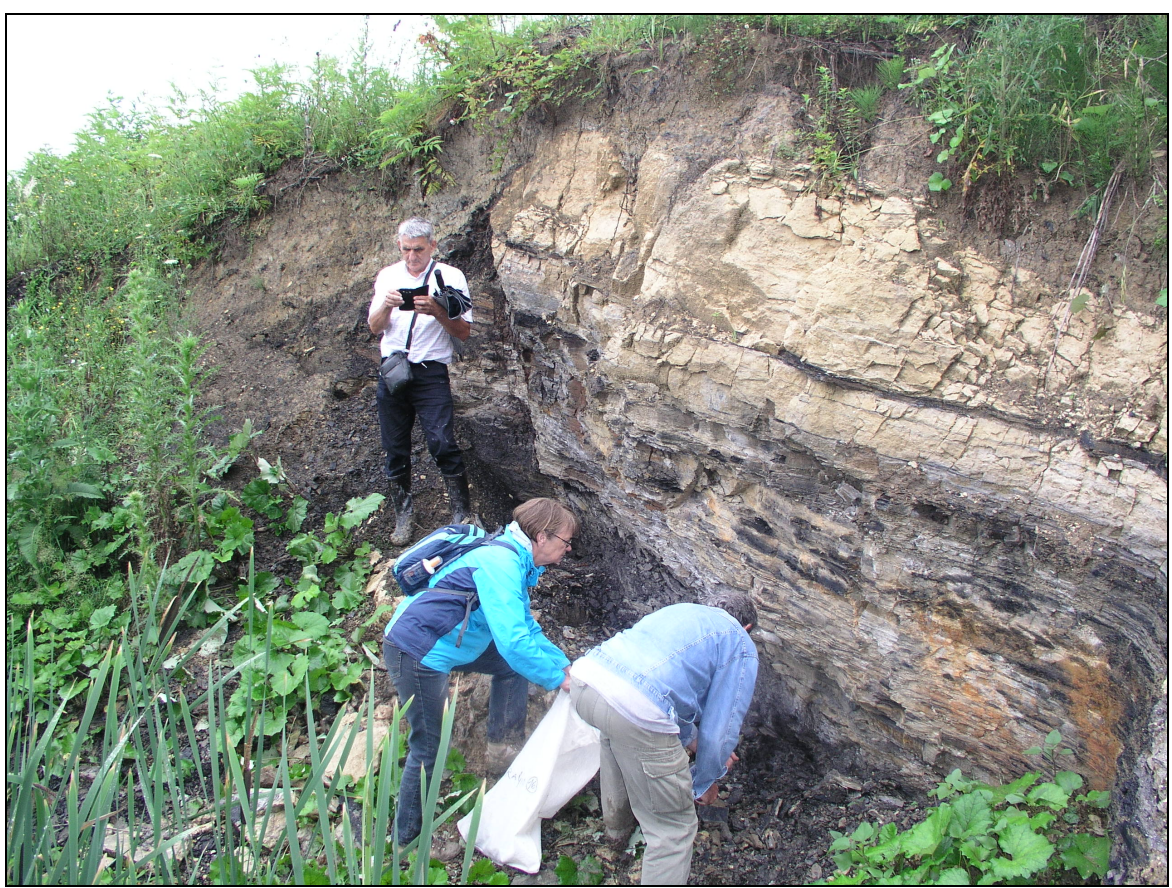

Fig. 6. - "Turija" - location 2. 


\section{Some scientific results}

The composition of the fossil rodent associations (Tab. 1) was compared with those from western Europe, Greece and Anatolia a geological age could be established and biogeographical provinces can be defined. The latest research of the Tertiary basins of the Central Balkans revealed the large similarity of forms belonging in the associations from Paragovo (Fruška Gora, Serbia) and Ugljevik - "Bogutovo Selo" (Bosnia and Herzegovina) (Marković et al. 2019). Both are of Late Oligocene age. The

Table 1. - List of the small mammals species from Tertiary localities in Bosnia and Herzegovina (de Bruijn et al. 2013, Stefen 2019, van der Sar et al. 2017, Wessels et al. 2008, 2010, 2016, 2019).

\begin{tabular}{|c|c|c|c|}
\hline & $\begin{array}{l}\text { Ugljevik: } \\
\text { "Bogutovo Selo" + } \\
\text { "Luke" Mezgraja }\end{array}$ & $\begin{array}{l}\text { Banoviči: } \\
\text { "Turija" }\end{array}$ & $\begin{array}{l}\text { Bugojno: } \\
\text { "Gračanica" }\end{array}$ \\
\hline Lagomorpha & & Oreolagus sp. & \\
\hline Marsupialia & Amphiperatherium sp. & $\begin{array}{l}\text { Amphiperatherium } \mathrm{cf} . \\
\text { exile }\end{array}$ & \\
\hline Insectivora & Erinaceinae sp. & $\begin{array}{l}\text { Erinaceinae } \\
\quad \text { gen. et sp. indet. } \\
\text { Desmanodon aff. zegleri } \\
\text { Desmanodon } \mathrm{sp} \text {. } \\
\text { Geotripus } \mathrm{sp} \text {. } \\
\text { Suleimania } \text { aff. ruemkae } \\
\text { ?Crocidosorex sp. } \\
\text { ?Srinitium } \mathrm{sp} . \\
\text { Oligosorex } \mathrm{sp} .1 \\
\text { Oligosorex } \mathrm{sp} .2 \\
\text { Heterosoricidae } \\
\text { gen. et } \mathrm{sp} \text {. indet. }\end{array}$ & $\begin{array}{l}\text { Soricidae indet. } \\
\text { Insectivora indet. }\end{array}$ \\
\hline Rodentia & $\begin{array}{l}\text { Deperetomys } \\
\text { calefactum n.sp. } \\
\text { Eucricetodon } \\
\quad \text { (Atavocricetodon) sp. } \\
\text { Bransatoglis fugax } \\
\text { Ctenodactylidae } \\
\text { gen. B sp.1 } \\
\text { Sayimys sp. indet. } \\
\text { Eomys sp. indet. }\end{array}$ & $\begin{array}{l}\text { Palaeosciurus } \\
\text { aff. P. feignouxi } \\
\text { ?Ratufa obtusidens } \\
\text { Bransatoglis } \\
\text { bosniensis } \mathrm{n} . \mathrm{sp} . \\
\text { Bransatoglis fugax } \\
\text { Microdyromys } \\
\text { cf. monspeliensis } \\
\text { Deperetomys } \\
\text { magnus } \mathrm{n} . \mathrm{sp} . \\
\text { Mirrabella } \text { aff. anatolica } \\
\text { Eumyarion } \\
\text { margueritae } \mathrm{n} . \mathrm{sp} . \\
\text { Eumyarion microps } \\
\text { Vetusspalax } \\
\text { progressus } \mathrm{n} \text {. gen. n. sp. }\end{array}$ & $\begin{array}{l}\text { Democricetodon } \\
\quad \text { mutilus } \\
\text { Democricetodon } \\
\quad \text { gracilis } \\
\text { Stenefiber } \\
\quad \text { depereti }\end{array}$ \\
\hline
\end{tabular}


Paragovo fauna was discovered in 2017 and is currently being studied. The Paragovo and Ugljevik faunas are at the base of, or below the first sediments of the Pannonian basin and thus suggest an age estimate for the start of subsidence in that basin.

Most of the faunal elements in the faunas are different from those of Western and Central Europe suggesting that the seaways located where now the Alpine mountains are, formed a barrier for faunal exchange. Instead many elements from the Balkan resemble Asian animals, in particular those from Anatolia.

The result of the research in Bosnia and Herzegovina are of great importance for the study of migration pathways, and the evolution of climate and environment of the Balkan. The Bosnia and Herzegovina reconnaissance, conducted in 2018, will contribute to more efficient planning and work in the upcoming years. Unfortunately, it is difficult to explore natural outcrops in the country's territory due to the danger of explosive devices (mines) left behind after the wars.

\section{Acknowledgements}

We would like to thank the Geological Services of RiTE Ugljevik, RMU Banovići and RU Gračanica. Especially thanks to our colleagues Peja Jović, Rajko Tomić, Zlatko Ječmenica, Stanko Jokanović, Pero Rikić, Nedžad Salkić, Elvis Nurković, Tvrtko Ćubela and Branko Grahovac for their help, cordiality and professional guidance during our stay in the coal mines in "Bogutovo Selo", "Luke-Mezgraja", "Turija", "Tušnica" and "Gračanica". We also express our gratitude to our colleagues Gudrun Daxner-Höck and Oleg Mandic from the Natural History Museum in Vienna for their support during the 2007 survey. Thanks to our friends Bert van der Zwaan and Ellen Maarschalkerweerd, who made our stay and work in Bosnia in 2018 more easier and very pleasant. Jes de Bruijn deserves a special place. She spent all these years of our joint work with us and she managed to make that every moment looks like we a family and at home. Thanks so much for that!

\section{REFERENCES}

Aiglstorfer, M., Mayda, S. (2018): Ruminantia from the middle Miocene of the Gračanica coalmine (Bugojno Basin, Bosnia and Herzegovina). In: Göhlich, U. B., Mandic, O. (ed.): The drowning swamp of Gračanica (Bosnia and Herzegovina) - a diversity hotspot from the middle Miocene in the Bugojno Basin. - Palaeobiodiversity and Palaeoenvironments: (On line first). [https://doi.org/10.1007/s12549-018-0354-z] 
Bastl, K., Nagel, D., Morlo, M., Göhlich, U. B. (2018): The Carnivora (Mammalia) from the middle Miocene locality of Gračanica (Bugojno Basin, Gornji Vakuf, Bosnia and Herzegovina). In: Göhlich, U. B., Mandic, O. (ed.): The drowning swamp of Gračanica (Bosnia and Herzegovina) - a diversity hotspot from the middle Miocene in the Bugojno Basin. - Palaeobiodiversity and Palaeoenvironments: (On line first). [https://doi.org/10.1007/s12549-018-0353-0]

Becker, D., Tissier, J. (2019): Rhinocerotidae from the early middle Miocene locality Gračanica (Bugojno Basin, Bosnia-Herzegovina). In: Göhlich, U. B., Mandic, O. (ed.): The drowning swamp of Gračanica (Bosnia and Herzegovina) - a diversity hotspot from the middle Miocene in the Bugojno Basin. - Palaeobiodiversity and Palaeoenvironments: (On line first). [https://doi.org/10.1007/s12549-018-0352-1]

Bruijn, H. de, Marković, Z., Wessels, W. (2013): Late Oligocene rodents from Banovići (Bosnia and Herzegovina). - Palaeodiversity 6: 63-105.

Coombs, M. M, Göhlich, U. B. (2019): Anisodon (Perissodactyla, Chalicotheriinae) from the middle Miocene locality Gračanica (Bugojno Basin, Gornji Vakuf, Bosnia and Herzegovina). In: Göhlich, U. B., Mandic, O. (ed.): The drowning swamp of Gračanica (Bosnia and Herzegovina) - a diversity hotspot from the middle Miocene in the Bugojno Basin. - Palaeobiodiversity and Palaeoenvironments: On line first. [https://doi.org/10.1007/s12549-018-0357-9]

Laskarev. V. (1925): Sur la trouvaille des Antliracothérides en Serbie et en Bosnie. - Annales géologique de la Peninsula balkanique 8: 85-92.

Leeuw, A. de, Mandic, O., Bruijn, H. de, Marković, Z., Reumer, J., Wessels, W., Šišić, E., Krijgsman, W. (2011): Magnetostratigraphy and small mammals of the Late Oligocene Banovići basin in NE Bosnia and Herzegovina. Palaeogeography, Palaeoclimatology, Palaeoecology 310: 400-412. [doi:10.1016/ j.palaeo.2011.08.001]

Malez, M., Slišković, T. (1976): Starost nekih naslaga ugljena u tercijaru Bosne i Hercegovine na osnovi nalaza vertebrata. - Geološki glasnik 21: 39-56.

Malez, M., Thenius E. (1985): Über das Vorkommen von Amynodonten (Rhinocerotoidea, Mammalia) im Oligo-Miozän von Bosnien (Jugoslawien). Paleaontologica Jugoslavica 34: 1-26.

Marković, Z., Bruijn, H., van de Weerd, A. A., van de Wessels, W. (2019): Deperetomys (Rodentia, Muridae) from the Oligocene of Serbia and BosniaHerzegovina. - Palaeobiodiversity and Palaeoenvironments. (In press)

Muftić, M., Luburić, P. (1963): Prilog poznavanju litostratigrafskih i tektonskih odnosa jezerskog neogena u Bosni i Hercegovini. - Geološki glasnik 7: 103-130.

Stefen, C. (2019): The castorids (Mammalia, Castoridae) from the (early) middle Miocene of Gračanica (Bosnia-Herzegovina). In: Göhlich, U.B., Mandic, O. (ed.): The drowning swamp of Gračanica (Bosnia and Herzegovina) - a diversity hotspot from the middle Miocene in the Bugojno Basin. Palaeobiodiversity and Palaeoenvironments: (On line first). [https://doi.org/10. 1007/s12549-018-0365-9]

Van der Sar, F. N., Van Glabbeek, R, Wessels, W., Marković, Z, Bruijn, H. de. (2017): Insectivores and marsupials from the upper Oligocene of Banovići 
(Bosnia and Herzegovina). - Journal of Vertebrate Paleontology 37/6: 1-17. [doi: 10.1080/02724634.2017.1368529]

Vrabac, S., Fejfar, O., Ćorić, S., Ferhatbegović, Z., Šišić, E. (2005): O prvom nalasku fosilnog sisara u ugljonosnom bazenu Banovići. - Zbornik radova RGGF-a Univerziteta u Tuzli 28: 51-53.

Wessels W., Marković Z., Bruijn H. de, Daxner-Höck, G., Mandic, O., Šišić, E. (2008): Paleogeography of Late Oligocene to Miocene Rodentia from the western Dinaride-Anatolian Land. In: Geophysical Research Abstracts EGU General Assembly 2008: 10. - EGU, Vienna.

Wessels W., Marković Z., de Bruijn H. (2010): The early Miocene rodents from Turija (Banovici), Bosnia and Herzegovina. In: $19^{\text {th }}$ Congress of the CBGA (Carpathian-Balkan Geological Association). Abstracts volume. [CarpathianBalkan Geological Association, Sofia.] - Geologica Balcanica 39(1-2): 23-26.

Wessels, W., Bruijn, H. de, Marković, Z. (2016): Rodent assemblages from the early Miocene and Oligocene of Bosnia Herzegovina and Serbia. In: RCMNS Interim Colloquium - CGS Limnogeology Workshop-Lake-Basin-Evolution. Stratigraphy, Geodynamics, Climate, and Diversity of Past and Recent Lacustrine Systems: 33-34. - RCMNS, Zagreb.

Wessels, W., Bruijn, H. de, Marković, Z., Milivojević, M. (2019): Small mammals from the opencast lignite mine Gračanica (Bugojno, middle Miocene), Bosnia and Herzegovina. In: Göhlich, U. B., Mandic, O. (ed.): The drowning swamp of Gračanica (Bosnia and Herzegovina) - a diversity hotspot from the middle Miocene in the Bugojno Basin. - Palaeobiodiversity and Palaeoenvironments: (On line first). [https://doi.org/10.1007/s12549-018-0366-8]

\title{
ПАЛЕОНТОЛОШКА ИСТРАЖИВАЊА ФОСИЛНИХ СИТНИХ СИСАРА ИЗ ПОВРШИНСКИХ КОПОВА РУДНИКА УГЉА БОСНЕ И ХЕРЦЕГОВИНЕ - ПРЕГЛЕД РЕЗУЛТАТА
}

\author{
ЗОРАН МАРКОВИЋ, МИЛОШ МИЛИВОJЕВИЋ, HANS DE BRUIJN, \\ WILMA WESSELS, ANDREW A. VAN DE WEERD, СВЕTЛAHA РЕНОВИЦА, \\ ЕНЕС ШИШИЋ, КАСИМ МОДРИЋ
}

\section{Р Е 3 И М Е}

Систематична палеонтолошка ископавања фосилних остатака у површинским коповима угља у Босни и Херцеговини иницирана су наласцима сисара у угљу допремљеном из Угљевика у Природњачки музеј у Београду 1993. године. 
Истраживања екипе Природњачког музеја и стручњака Универзитета у Утрехту започињу 2004. године у површинском копу „Богутово Село“ (РиТЕ Угљевик), да би се 2006. године проширила на целу Босну и Херцеговину. Откривена су нова налазишта у копу „Турија“ (РМУ Бановићи), као и „Грачаница“ код Бугојна. Пронађене су нове асоцијације терцијарних сисара. На основу њих употпуњава се слика централног Балкана. Упоређењем састава асоцијација као и еволутивног степена њихових најкарактеристичнијих елемената, констатована је повезаност појединих басена, а самим тим и биогеографских провинција. Тако, на пример, на основу најновијих резултата утврђена је сличност форми из асоцијација Парагова и Угљевика.

Рекогносцирањем терена спроведеном 2018. године, откривени су фосилизовани остаци и у новом површинском копу „Луке-Мезграја“, у близини Угљевика. Они указују да је и у овом случају у питању фауна горњо-олигоценске старости. У површинском угљенокопу „Турија“, слој са олигоценским фосилима више не постоји јер се изглед самог копа потпуно изменио услед интензивне експлоатације сировине. На основу налаза „Грачанице“, констатована је средњомиоценска старост фосилоносних слојева.

Резултати истраживања у Босни и Херцеговини од великог су значаја за формирање јасне представе о миграторним путевима, укључујући и еволуцију и услове живота током терцијара у овом делу Европе.

Заједно са колегама из геолошких служби рудника планирана су будућа истраживања. 